develop exemplary solutions to address them. Research covers politics, society, economy, education, health and culture.

Address: Carl-Bertelsmann-Str. 256, 33311 Gütersloh, Germany. Website: http://www.bertelsmann-stiftung.de

Chairman: Dr Gunter Thielen.

\section{Brookings Institution}

Founded 1916. Independent, frequently cited as the world's best think tank. Goals are to strengthen American democracy; foster the economic and social welfare, security and opportunity of all Americans; and secure a more open, safe, prosperous and cooperative international system. Priority research areas include energy and climate, growth through innovation, managing global change, and opportunity and wellbeing.

Address: 1775 Massachusetts Ave., NW, Washington, D.C., 20036, USA.

Website: http://www.brookings.edu

President: Strobe Talbott.

\section{Bruegel}

Founded 2004. Independent European think tank working in the field of international economics. Research areas: emerging powers and global governance structures; Europe's macroeconomic and structural challenges; competitiveness, innovation and financial regulation; climate change and energy.

Address: Rue de la Charité 33, B-1210 Brussels, Belgium.

Website: http://www.bruegel.org

Director: Jean Pisani-Ferry.

\section{Carnegie Endowment for International Peace}

Founded 1910. Independent think tank specializing in international affairs with particular focus on Russia and Eurasia, China, the Indian subcontinent/South Asia, globalization, nonproliferation and security affairs. Aims to advance co-operation between nations and promote active international engagement by the USA and become 'the first truly multinational-ultimately global-think tank'. Offices in Washington, D.C., Moscow, Beijing, Beirut and Brussels.

Address: 1779 Massachusetts Ave., NW, Washington, D.C., 20036-2103, USA.

Website: http://www.carnegieendowment.org

President: Jessica T. Mathews.

\section{Carnegie Middle East Center}

Founded in 2006 as part of the Carnegie Endowment for International Peace's Middle East programme. Public policy think tank and research centre that aims to better inform the process of political change in the Arab Middle East and deepen understanding of the complex security and economic issues that affect it. Programmes: Middle East economies; Arab politics; regional relations; security.

Address: Lazarieh Tower, Building No 2026 1210, Fifth Floor, Emir Bechir St., Beirut, 11-1061 Riad El Solh, Lebanon.

Website: http://www.carnegie-mec.org

Director: Paul Salem.

\section{Carnegie Moscow Center}

Founded in 1994 as a subdivision of the Carnegie Endowment for International Peace. Analyzes the most important issues in international affairs and Russian domestic and foreign policy, as well as the regions they affect. Programmes: economic policy; foreign and security policy; non-proliferation; religion, society and security; Russian domestic politics and political intuitions; society and regions; the east-east: partnerships beyond borders.

Address: 16/2 Tverskaya, Moscow 125009, Russia.

Website: http://www.carnegie.ru

Director: Dmitry Trenin.

\section{Cato Institute}

Founded 1977. Non-profit public policy research foundation based on the principles of the American Revolution-limited government, free markets, individual liberty and peace. Comprises Centers for Constitutional Studies, Educational Freedom, Global Liberty and Prosperity, Representative Government and Trade Policy Studies.

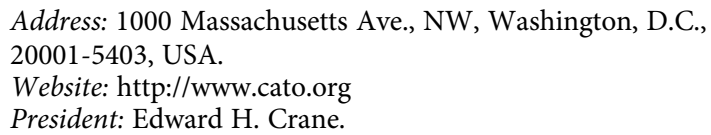

\section{Center for American Progress}

Founded 2003. Organization dedicated to improving the lives of Americans through progressive ideas and action. Research issues: domestic; economy; national security; energy and environment; media and progressive values.

Address: 1333 H St., NW, 10th Floor, Washington, D.C., 20005, USA.

Website: http://www.americanprogress.org

President: John Podesta.

\section{Center for Global Development}

Founded 2001. Independent, non-partisan and non-profit think tank that works to reduce global poverty and inequality. Research topics include: aid effectiveness; climate change; debt relief; education; global health policy; globalization; migration and development; trade.

Address: 1800 Massachusetts Ave., NW, Third Floor,

Washington, D.C., 20036, USA.

Website: http://www.cgdev.org

President: Nancy Birdsall.

\section{Center for International Governance Innovation}

Founded 2001. Independent, non-profit and non-partisan think tank that focuses on international governance. Research programmes: the global economy; the environment and energy; development; global security.

Address: 57 Erb St. West, Waterloo, Ontario, Canada N2L 6C2.

Website: http://www.cigionline.org

Executive Director: Thomas Bernes.

\section{Center for Strategic and International Studies}

Founded in 1962 during the Cold War to find ways for the USA to sustain its prominence and prosperity as a force for good in the world. Bipartisan, non-profit organization that conducts research and analysis and develops policy initiatives that look into the future and anticipate change. Research focuses on defence and security, energy and climate change, global health, global trends and forecasting, governance, human rights, technology, and trade and economics. 